\title{
Sustainable Civil Justice through Open Enforcement: The Ukrainian Experience
}

\author{
Iryna Izarova \\ Dr.Sc. (Law), Professor, Institute of Law, \\ Taras Shevchenko National University of Kyiv, \\ Kyiv, Ukraine
}

DOI: https://doi.org/10.36941/ajis-2020-0098

\section{Abstract}

Ukraine, which is a member of the Council of Europe and is firmly on the path to European integration, develops legislation and legal doctrine with the aim of the implementing European standards. The Association Agreement signed in 2014 set out to put into effect, in particular, the approximation of legislation, the strengthening of judicial cooperation etc. The comprehensive reforms taking place cover various areas of legal regulation, specifically, legal proceedings and the enforcement of judgments. This new legislation in the field of the judicial system was approved in Ukraine in 2015-2017. The low level of trust in the judiciary, inside as well as outside of Ukraine, causes economical relations to suffer increasingly. It impacts inter alia the circulation of judicial decisions between EU Member States and Ukraine, which is not unencumbered by this and may be described as uncertain at best. Regarding all of these, the first part of this paper is about the goal of civil justice definition and defining the enforcement part throughout the process of judicial rights protection in Ukraine. In the second part we are investigating the transitional issues of the creation of an open enforcement system in Ukraine, the challenges and ways to resolve them within the most current trends of sustainable development and inclusive justice. In the conclusion, some theoretical approaches are criticized due to the lack of attention to the very ideas of sustainable justice and a peaceful and strong institutions promotion, which elude the attention of the legislators. The way of its fruition of an open and peaceful judicial enforcement creation through proper goal definition were proposed.

Keywords: sustainable development, inclusive society, peace and strong institutions, civil justice, goals of civil justice, a fair trial, an open enforcement

\section{Introduction}

Today sustainable development plays a crucial role in all areas, the functionality and the evolving of processes included. In particular, Goal 16 (The Global Goals For Sustainable Development, Goal 16 (2015) set out the necessity of strong and peaceful institutions functioning with the aim of ensuring access to justice for all the members of peaceful and inclusive societies. Due to these, some legislative changes illustrate the pursuit to improve the national judiciary and legal proceedings, to increase the standards of access to justice. Ukraine is making huge efforts to reach these goals, too.

On-going reforms in civil justice and the judiciary as well as in related institutes are the result of a new paradigm of justice in Ukraine - since 1996 when the Constitution of Ukraine was adopted and the judiciary and related legislation were under reconstruction. Several reforms of civil justice happened during this period - the first edition of the Code of Civil Procedure of Ukraine (Civil 
Procedure Code of Ukraine, No. 1618-IV (2004), hereinafter CPC 2004) came into force in 2005 and is in effect to this day. The second great change happened in 2017, when the current edition of the CPC was adopted (Civil Procedure Code of Ukraine, No 2147-VIII (2017), hereinafter CPC 2017). The previous Code of Civil Procedure of the USSR 1963 (Civil Procedure Code, No 30 (1963), hereinafter CPC 1963) was approved on $18^{\text {th }}$ July 1963 and was in force until 2005, throughout the entire period of Ukraine being a part of the SU and up to the codification of civil procedural law in the independent Ukraine.

We should emphasize, that civil and commercial cases in Ukraine are considered by different courts and regulated by different procedural codes. One of the first codes of an independent Ukraine was the Commercial Procedure Code of $6^{\text {th }}$ November 1991 which defined the jurisdiction and the powers of commercial courts, as well as the peculiarities of commercial cases consideration.

Assessing the value of the CPC 2004, it should be noted, that each code of civil procedure reflects government policies and ideas on how to implement justice in civil cases and reflects the constitutional principles of justice. The expectations of the Ukrainian society were associated with changes, not only of the procedure, but mostly with the result of the judicial case consideration - the real enforcement of the decisions.

The ECtHR in his decisions outlined the necessity of a complex reformation of the Ukrainian judiciary and enforcement, specifically, in his famous decision of the Yuriy Ivanov vs. Ukraine case. Recently, the ECHR has adopted a unique solution in the case of Burmych and others vs. Ukraine, which again confirmed the existence of systematic problems.

The bill of amendments to the legislative acts No 6232 (The bill of amendments to the Commercial Code of Ukraine, Civil Procedural Code of Ukraine, the Code of Administrative Procedure of Ukraine and other legislative acts No 6232 (2017)) came into force on the commencement of the work of the new Supreme Court of Ukraine as a cassation instance court on the $15^{\text {th }}$ December 2017 .

On $2^{\text {nd }}$ June 2016 two laws were adopted in Ukraine, which initiated the development of a qualitatively new system of the execution of court decisions. These are the Law "On Enforcement Proceedings" No. 1404-VIII and "On the Bodies and Persons Who Execute the Enforcement of Court Decisions and Decisions of Other Bodies" No. 1403-VIII. These laws define the basis for the organization and activities for the enforcement of court decisions and decisions of other bodies (officials) by the bodies of the state executive service and private executors, their tasks and legal status, as well as the procedure for executing enforcement proceedings.

The active reformation of the system of execution of court decisions in Ukraine has lasted for decades and is, unfortunately, without any significant achievements- the statistics are unsatisfactory and so far only minor court decisions have been executed. In addition, the statistics on the enforcement of court decisions are non-transparent, which makes it almost impossible for the public to control the justice system in the country.

In particular, we should underline, that there are no official statistics on the enforcement of judgments in Ukraine. Valid and relevant information about this can only be found in the Minister of Justice's speeches and in just a few reports, available on their website.

For instance, in 2017, Pavlo Petrenko, the previous minister of justice, has noted that the level of enforcement of court decisions in Ukraine has increased threefold - from 5-6\% to $18 \%$ due to the introduction of incentives for state enforcement officers in the form of percentages of moneys collected and the launch of the Institute of Private Enforcement Agents (Interfax Ukraine (2017, December 06). The level of execution of court decisions in Ukraine has tripled in a year - the Minister of Justice). All further inquiries refer simply to these words without specifying the methodology and results of the actual execution of court decisions in the state. Up to date information without any details, concerning the data of enforcement is known from the presentation of the vice minister in 2019 (Ministry of Justice of Ukraine (2019, August 13). The State execution office presented the results of their work in the first part of the year 2019).

It should be added that the EU implementation problem is not solved either. The enforcement 
of court decisions is also important for the efficiency of a justice system, however, comparable data are not available in most Member States (The 2019 EU Justice Scoreboard).

Therefore, the significant transformations taking place in the Ukrainian society, the intensification of the European integration process and the desire to join the European community, as well as reaching a real effective rights protection with the enforced court decisions have brought about the necessity of a complex global reform of civil justice in Ukraine.

Whereas effective and sustainable civil justice is impossible without proper functioning of the enforcement, we are going to define the most important gaps of the national doctrine, which are making the problems of the decisions enforcement in Ukraine and a sustainable civil justice creation inevitable. Some remarks concerning the issues of the recognition and enforcement of foreign judicial decisions have been outlined for the creation of a complex picture.

\section{What Does the Goal of Civil Justice Mean?}

Civil justice today has many faces.

Uzelac Alan, Goals of Civil Justice and Civil Procedure in Contemporary Judicial Systems

The structure of the CPC 2004 of Ukraine was similar to the CPC 1963, but it also included several new and important institutions of civil procedural law, which indicated a change in the basic approach to the meaning of justice in civil matters, introduced the idea of the rule of law and took into account international standards for civil proceedings. This was the result of the change of approach to the definition of the main goal of Civil Procedure, which is reflected in its structure.

The goal of civil justice is an important mark that symbolizes the direction of civil procedural law and its role in the implementation of justice. As was correctly emphasized by Uzelac (2014), it would be easy to state the obvious and repeat that in all justice systems of the world the role of civil justice is to apply the relevant substantive law to the established facts in an impartial manner and to pronounce fair and accurate judgments, but this is not so (Uzelac, 2014). The changes in the formulation of the purpose of civil justice in Ukraine is associated with modern reforms. We will further focus on the peculiarities of defining the goal or main objective of civil justice in the national legislation of Ukraine.

Article 2 of the CPC 2017 contains an item on the objectives and the basic principles of Civil Procedure in Ukraine, which states that the task of the civil justice system is a fair, impartial and timely consideration and resolution of civil cases for the effective protection of violated rights and freedoms. The court and those who take part in the trial are required to be guided by the above mentioned provisions that prevail over any other considerations in the judicial process.

This approach to define the basic goal of civil procedure indicates the evolutionary transition to a new stage of its development, as the exercise of justice defines the role of judges and participants. In the CPC 1963 the main task of civil justice was defined in Article 2 of the CPC 1963, where it was identified as the protection of rights and legal interests belonging to individuals, legal entities and the state by thorough consideration and resolution of civil cases in full accordance with applicable law (as amended on 23 January 1981).

During the preparation of the CPC 2004 it was decided to change the basic approach to defining the main goal of civil procedure by consolidating its provisions in the following form: the CPC 2004 is supposed to ensure the proper functioning of the judicial system by conducting proceedings in civil cases in courts in accordance with the Constitution of Ukraine and other laws of Ukraine. It allows courts to implement their duties so as to ensure proper and timely consideration and resolution of civil cases for the protection of both violated or disputed rights and freedoms belonging to individuals and businesses, as well as public health and public interest (Explanatory Statement for the Draft of Civil Procedure Code of Ukraine (2004).

The CPC 2004 stated that the task of justice is not the guarding, but the protection of rights when they are violated, unrecognized or disputed. Also the definition of the object of protection was 
changed to 'the rights, freedoms or interests belonging to individuals and legal persons as well as the protection of state and public interests'. The final version was amended and approved in the first article, which provides for the protection of rights, freedoms and interests of individuals, the rights and interests of legal entities and state interests.

This approach, which is reflected today in the CPC 2017 as a result of the reform, shows paradigmatic changes that have taken place in the Ukrainian society and the law. The introduction of more effective and realistic tools for ensuring everyone's right to effective means is an international obligation of Ukraine, which it has assumed by signing the European Convention. Unfortunately, in numerous decisions of the ECHR it is mentioned that our country still cannot provide the appropriate level of such protection (European Court of Human Rights. Ukraine (2020, January). But it is worth noting that we are making efforts in this sphere, which is proven by the reform of civil justice.

Ensuring the effectiveness of judicial protection of rights has led to changes in the structure of the CPC 2017, among which there are new provisions for simplified proceedings, improved rules for order proceedings, etc., in general, the structure of the CPC 2017 reflects its contents and now includes 11 sections comprising 503 articles. Although the CPC 2017 includes only one procedure with the aim of the settlement of a dispute, we have no settlement obligations for the parties or any stimulus for them to settle their dispute. In addition, we have no compulsory ADR nor any compulsory legal aid, but unlimited jurisdiction to any case consideration in court. This leads to an enormous number of cases in courts, specifically, in Ukraine more than 4 million cases are considered in courts yearly. One of the additional consequences of this approach are the difficulties of the decision enforcement due to the small claims value and impossibility of enforcement of particular decisions. Therefore, the effectiveness of civil justice was announced, but not implemented in specific norms and institutes of the civil procedure.

In our opinion, the idea of Goal 16 of effective, accountable and inclusive institutions might be reached through a more settlement-directed and give-and-take character of the procedure, which may be implemented more effectively with the help of a judge and an attorney to assist in a settlement, rather than by the traditional way of court consideration. The real purpose of the claimant is the protection of his rights and continuing to be able to participate in social life, in particular, saving relations with the other party of the dispute. Therefore, the proper goal of sustainable justice should touch the peaceful dispute settlement with the aim of good relations being preserved between all the disputes 'participants.

\section{Implementation of Court Decisions: The Way of Transformation}

\subsection{Bodies and Persons Who Enforce Court Decisions and other Decisions}

The enforcement reform seems one of the most important due to its meaning - even the best civil procedure is empty without the real implementation of the judicial decision and rights protection. Thus, the new vision of the current model of the enforcement in Ukraine as an open and mixed structure is studied in this paper too.

In accordance with the Law of Ukraine, "On the Bodies and Persons Who Execute the Enforcement of Court Decisions and Decisions of Other Bodies" (2016), the enforcement of court decisions and the decisions of other officials is entrusted to bodies of the state executive service and private executors. The latter may act only in the cases specified in the Law of Ukraine "On Enforcement Proceedings" (2016).

The system of enforcement bodies is comprised of the Ministry of Justice of Ukraine and the bodies of the State Bailiffs' Service, established by the Ministry of Justice of Ukraine in accordance with the procedure established by law.

The Law of Ukraine "On Enforcement Proceedings" (2016) states that the enforcement of decisions is entrusted to bodies of the state executive service (state executors) and, in cases provided 
for by this Law, to private executors whose legal status and organization of activities are established by the Law of Ukraine "On the Bodies and Persons Who Execute the Enforcement of Court Decisions and Decisions of Other Bodies" (2016).

Government executors are representatives of the authorities, acting on behalf of the state and under its protection and authorized by the state to carry out activities for the enforcement of decisions in the manner prescribed by law. According to the law, state executors are executors of the bodies of the state executive service, their deputies, chief state executors, senior state executors and state executors of the bodies of the state executive service.

Private executors are subjects of independent professional activity, who may be citizens of Ukraine, authorized by the state to engage in enforcement activities in accordance with the procedure established by law.

In accordance with the Law of Ukraine "On Enforcement Proceedings" (2016) a private executor cannot enforce the decisions on the removal and transferral of a child, establish a meeting with him/her or remove obstacles in meeting with a child. Neither can a private executor enforce decisions, according to which the debtor is a legal entity or enforce the realization of property, which is prohibited in accordance with the law (the full list may be found in the Law of Ukraine "On Bodies and Persons who Execute Enforcement of Court Decisions and Decisions of Other Bodies" (2016).

In cases stipulated by law, decisions on the collection of property and funds are executed by revenue and fee bodies and the decisions on the collection of funds are made by banks and other financial institutions. The decision on the collection of funds from state bodies, state and local budgets or budgetary institutions is carried out by bodies that execute treasury services of budget funds.

For this specific issue, we may emphasize, that the powers of the private and state executors are not equal and it seems that the privatizing of the enforcement was not the priority of the on-going reform. The private part of this mixed system of enforcement in Ukraine should be stronger, more innovative and include equal possibilities with the state officers.

The idea of effective, accountable and inclusive institutions, developed in SDG 16, in our view, may be implemented in the enforcement with the joining of mediators and other ADR subjects for settling the execution of the decision within the enforcing procedure. This would help to create a more sustainable and inclusive justice at this particular stage of the rights protection.

\subsection{Peculiarities of Enforcement Proceedings}

The concept of "enforcement proceedings" secured in the legislation of Ukraine as a whole reflects the approaches that are the customary practice of the ECHR and CoE recommendations. According to the Law of Ukraine "On Enforcement Proceedings" (2016), these proceedings are the final stage in judicial proceedings and the enforcement of court decisions and decisions of other bodies (officials). They are a combination of actions of bodies and individuals which are aimed at enforcing decisions and are conducted in line with the Constitution and the laws of Ukraine, as well as with the decisions that are subject to compulsory enforcement.

The general principles of enforcement are the rule of law; mandatory implementation of decisions; legality; discretion; fairness; impartiality and objectivity; transparency and openness of executive proceedings; the reasonableness of the terms of enforcement proceedings; proportionality of measures of enforcement of decisions and the volume of claims by decisions; ensuring the right to appeal against decisions, actions or omissions of state executives and private executors.

The decisions that are subject to enforcement, as well as the executive documents, are defined in Article 3 of the Law of Ukraine "On Enforcement Proceedings" (2016).

The enforcement proceedings are carried out in the following order:

1. The beginning of the enforcement of a decision, when the executor carries out the execution of a decision on the basis of an executive document, as well as on the application of the collector on the enforcement of the decision and other grounds according to the law. 
2. The transmission of enforcement documents, when copies of the executive orders and other documents of enforcement proceedings are brought by the executor to the attention of the parties and other participants in the enforcement proceedings, via post or delivered by a courier. The exception are the cases, when the decisions on the opening of enforcement proceedings or on the return of an executive document to the collector or a notice to the collector about the return of the executive document without acceptance, therefore, these documents are sent by a recommended letter with the receipt on the delivery.

In accordance with the current legislation, the debtor is considered to be notified of the beginning of the enforcement of decisions, if the order to open an enforcement proceeding has been sent to the address specified in the executive document. In case the executive document contains e-mail addresses of the collector and/or the debtor, the enforcement proceedings documents are also sent to the collector and/or the debtor by e-mail.

3. The conduct of executive actions in accordance with the rules established by law. Possible complications are:

1) Postponement of the conduct of executive actions in the presence of circumstances preventing the conduct of executive actions (illness of the party of enforcement proceedings, business trip of the party of enforcement proceedings, natural disaster, etc.), or on other grounds, due to the emergence of which the parties were deprived of the opportunity to take advantage of their rights for up to 10 working days.

2) Suspension or installment of execution, establishment or change of the method and procedure for execution of the decision in the presence of circumstances that complicate the execution of the decision or make it impossible (illness of the party of enforcement proceedings, business trips of the enforcement party, natural disaster, etc.), on the application of the parties to the court, which considered the case as a court of first instance, for a deferral or installment of a decision.

3) Suspension of conduct of executive actions in the case, determined by law. It is also possible to suspend enforcement proceedings in case of the court updating the time limit for filing an appeal or accepting such an appeal in accordance with Article 38.

4) The search of the debtor, his property, the search for the child in accordance with the executive document on the taking away a child - in the absence of information about the place of residence, the residence of the debtor who is an individual, as well as the child in accordance with the executive documents on the taking away a child on the basis of a court order regarding the search of the debtor or the child.

5) The return of the enforcement document to the collector, on the grounds, specified by law, for instance, if the collector submitted a written application for the return of the enforcement document or the debtor does not have any property that can be collected, and measures taken by the executor under this Law to find such property proved to be ineffective.

4. The termination of enforcement proceedings on the grounds, specified by law, for instance, recognition by the court of the refusal of the recovery of the enforcement of a court decision or the court's approval of a settlement agreement concluded by the parties in the course of execution of the decision.

As we can see, the enforcement procedure does not contain any possible settlement proceedings, pushing the participants to the peaceful agreement, which should be recognized as ineffective. At the stage of implementation of the judicial decision, regarding all these possibilities for conduct or terminating the enforcement, if the debtor does not agree and is unwilling to pay, we should pay more attention to his reasons and use all the possibilities to settle the dispute amicably.

\section{$3 \cdot 3$}

Open Enforcement as a Saving Way for Effectiveness and Sustainability

An open and fair trial is an integral part of the concept of rule of law and access to justice is 
mandatory in the wording of the Universal Declaration of Human Rights and the European Convention of Human Rights. The enforcement of the judicial decision is an integral part of the trial according to the ECtHR case-law. Due to this, the transparency of enforcement plays a crucial role in the proper functioning of the judiciary in a democratic and law-based state with a peaceful and inclusive society.

According to the CoE Recommendation on enforcement (2003), enforcement procedures should be as effective and efficient as possible and any legislation should be sufficiently detailed to provide legal certainty and transparency of the process.

In the Guidelines for a better implementation of the existing Council of Europe recommendation on enforcement (2009) the information accessible to the claimant was highlighted. In particular, in order to ensure the claimant's right to adequate assistance in the enforcement proceedings, the access to public registers should be available with the aim to confirm essential information about the defendant. For instance, this might be information about identifying the defendant and his whereabouts for enforcement purposes, or the data accessible through public registers (i.e. land registers, court registers of companies, etc.), which are subject to the freedom of information and data protections laws of the national state (39 art.).

Ukraine is a CoE member-state and the Ukrainian experience in the creation of free and full access to judicial decisions is unique. The access to all the judicial decisions, including interim court orders and final judicial judgments, according to the Law «On the access to the judicial decisions» (2005) are available on the web-site through the Single state register of the judicial decisions http://reyestr.court.gov.ua . This idea was implemented taking into account the need to ensure public access to judicial acts, as well as to prevent any abuse, in particular, by amending or changing a court decision, which has been announced previously (Lesiuk, 2005: 17).

In addition, an automated system of executive proceedings ${ }^{1}$, through which the registration of executive documents, documents of executive proceedings, as well as the executive acts, was implemented in Ukraine (See more Snidevych (2019) and Turkanova (2020)).

The procedure for its operation is determined by the Ministry of Justice of Ukraine, which provides free public access to its official website, where the information is available and can be researched, read and printed without the need for special software and without any restrictions 24 hours a day.

This system provides an objective and impartial distribution of executive documents between state executives; provision of information on enforcement proceedings to the parties to enforcement proceedings; the production of documents for enforcement proceedings; centralized storage of documents for enforcement proceedings; centralized storage of information on the accounts of the bodies of the state executive service and private executors that are open for the purposes of enforcement proceedings; preparation of statistical data; registration of incoming and outgoing correspondence and stages of its progress; transfer of documents of enforcement proceedings to the electronic archive; formation of the Uniform Register of Debtors (hereinafter URD) according to the Law of Ukraine "On Enforcement Proceedings" (2016).

The URD is a systematic database of debtors, which is part of an automated system of enforcement, is aimed at disclosing information in real time on persons 'debts and preventing the debtors from disposing of property through the website https://erb.minjust.gov.ua/\#/search-debtors and is maintained by the Ministry of Justice of Ukraine.

The lack of information on the actual enforcement of court decisions makes it impossible to monitor and evaluate this type of activity. Currently, the only up-to-date and accessible statistical information on the Ministry of Justices website is related to only one oblast of Ukraine - "Evaluation of the work of state executive service bodies of the Main Territorial Directorate of Justice in Kherson

\footnotetext{
${ }^{1}$ The web page of this system can be found here https://asvpweb.minjust.gov.ua/\#/search-debtors
} 
Oblast". It shows that out of 16386 executive documents completed only 1112, which is less than $7 \%$, and 448 were actually executed! That is just $2.7 \%$ of the enforcement documents for the collection of periodic payments in the first half of 2019 (Single State Web-Portal of Open Data (2019)

Even so, the information already mentioned by the Deputy Minister earlier in this article contains a much more positive assessment of the performance of the executive service, in particular, according to her data overall, the number of documents actually completed increased by $23.3 \%$ compared to the same period in 2018 (Ministry of Justice of Ukraine (2019, August 13).

This is a result of the opacity and unavailability of the actual performance information, both the overall results and the intermediate ones, which, if made public, would make it possible to realistically evaluate and understand the problems that exist in this area.

It should be noted, that some information related to the enforcement of judicial decisions are available from time to time at science conferences, in particular when EU and CE representatives participate. This shows the interest in these specific areas of the European institutions and the possibilities our authorities have to provide such an information, for instance, concerning cases against state companies (total debt on enforcement approximately 150 bn. euro in 2018 as it was stated during the conference and in a report related to a visit to Ukraine with the aim of bilateral consultations related to the enforcement development in August 2018).

In our opinion, this detailed information on the enforcement of court decisions should be placed, in particular, on the Open Data Portal (the Single State Open Source Web Portal) https://data.gov.ua/dataset?groups=iustytsiia , which was created at the request of the Law of Ukraine "On Access to Public Information" (2005) and the Decree "On Approval of the Provision on Datasets to be Disclosed in the Form of Open Data" No. 835 (2015) by the State Agency for Issues eGovernment of Ukraine. This Portal is intended to provide access to public information in the form of open data and provides for access to information by public authorities with the possibility of its subsequent use.

We may title this as a first stage of a truly open enforcement system creation through the open registers of proceedings and debtors. Nevertheless, strong and peaceful institutions in the Goal 16 wording, in our view, means not only information about proceedings and parties, but more transparent communication between parties and enforcement agents at all stages of the proceeding, in particular through the creation of an online platform of enforcement. Such a platform would facilitate a multilevel access for agents, parties and the public for enforcement process developments. It would allow easy access for mediators or other ADR specialists to insure a peaceful and effective implementation of the decision. It should help to reduce time and money spent for enforcing the judicial decision too, which should be taken into account due to court fees, which are paid by the parties during court consideration.

In addition, we may resolve the Gordian Knot of the absence of transparent information concerning the enforcement of judicial decisions in Ukraine. In particular, we may study the number and quality of cases, approaches to enforcement of decisions, concrete methods of civil rights implementation etc. We should definitely get access to data, as to where the particular claimant gets satisfaction, when and in what amount; and vice versa we should have the information that a decision was not executed, in order to be able to improve these issues.

\section{Concluding Remarks}

The sustainability of civil justice with the aim of rights protection, in our view, is determined by two factors: the existence of an effective and flexible procedure of case consideration and an open and flexible enforcement of judgments. The first is related to what the goal of civil litigation really is, in particular, the rights protection and whether the law sufficiently regulates conciliation procedures, which means flexibility in resolving a dispute. The second part is related to the existence of an effective system of enforcement bodies, ensuring open enforcement proceedings. Sustainability means the certainty and the level of trust to the relevant limits. Flexibility or the possibility of a peaceful resolution of the dispute by the parties could be the most effective justice, combining this 
with open trial and open enforcement, which would ensure the possibility of control and avoid endless rights protection during the numbers of proceedings to reach it.

All the reforms, taking place in various areas of the judicial system, legal proceedings and enforcement of judgments in Ukraine, aim to rise to a level of trust of the judiciary inside and outside of Ukraine and in Member States. Undoubtedly that access to justice and fair litigation in a reasonable time is crucially important to the economical relations development and, in our view, open enforcement is a tremendous issue for mutual trust and the free circulation of foreign decisions in Ukraine and in the EU.

On the way to sustainable and effective civil justice, it is important not only to enforce domestic judgments, but also those of foreign courts. A high level of protection of rights will definitely promote the development of economic relations between different countries, in particular, within the framework of a comprehensive free trade area between Ukraine and the EU. At the same time, outdated and ineffective approaches to the recognition and enforcement of decisions of foreign states, which limit the circulation of court decisions and significantly reduce the capacity of creditors, will be a significant obstacle to the development of economic relations, especially for small and medium-sized businesses.

Though, changes of the goals of civil justice in 2017 should be deemed as a proper ground for developing an effective rights protection in Ukraine. Specifically, the civil disputes resolution should become timely and fully implemented through a fair trial and the subsequent enforcing of a decision.

The effectiveness of civil justice, which was announced, should be within the idea of sustainable development, in particular, supporting the peacefulness and justice of state institutions, underlined in SDG 16. It helps to implement an idea of social relations regulated not only by state courts, but with their own amicable forces. Therefore, various friendly proceedings aimed at the peaceful agreement of parties, should be implemented in specific norms and institutes of the civil procedure and enforcement as well.

Vice versa, the CPC 2017 includes only one procedure with the aim of an amicable settlement of a dispute, which should lead to the amicable resolution of the case by parties and prevent review and enforcement of the decision as well. An unlimited jurisdiction stimulates citizens to apply to court for any reason, which are often not worth a judicial review due to its small value or the absence of a legal dispute regulation. In addition, the lack of professional compulsory legal aid and tradition of legal advice in Ukraine stimulate the increase of court submissions for any and all reasons.

With the peaceful and amicable dispute resolution as a goal of the civil litigation we may create a more effective and a genuine sustainable justice.

We may underline also, that the power of the private executors and mediators within peaceful settlement are deemed more attractive and fruitful and should be the priority of the on-going reform. Also the mixed system of enforcement in Ukraine should be stronger and more innovative too, including equal possibilities of other enforcement agencies with the state officers.

The enforcement procedure should contain settlement proceedings, encouraging the participants to come to a peaceful agreement, which would make the enforcement more effective and fruitful. Within this particular settlement, the reasons of the debtor's willingness could be discovered and might be solved amicably through joint efforts.

In addition, open sources of enforcement proceedings would play a crucial role in creating a transparent system of enforcing the judicial decisions. We should see this face of justice, paraphrasing the epigraph. In particular it makes available for the public the issues of the specific procedure of the decision enforcement and its results. That is a proper ground for raising the level of trust in the judiciary and the enforcement, as well as the creation of a genuine sustainable civil justice in general. 


\section{References}

Cappelletti, M. (1970-1971) Social and Political Aspects of Civil Procedure - Reforms and Trends in Western and Eastern Europe. Michigan Law Review Association, 69 (5), 847-886. DOI 10.2307/1287304.

Council of Europe. Good practice guide on enforcement of judicial decisions (2015, December 10-11). Retrived from https://rm.coe.int/european-commission-for-the-efficiency-of-justice-cepej-good-practice-/16807477bf .

Council of Europe. The Guidelines for a better implementation of the existing Council of Europe recommendation on enforcement (2009, December 17). Retrieved from https://rm.coe.int $/ 16807473 \mathrm{~cd}$.

Council of Judges of Ukraine (2018, July 11). In 2017, the number of executed court decisions in civil and commercial cases in Ukraine has been tripled (in Ukrainian). Retrieved from http://rsu.gov.ua/ua/news/za-2017-rik-vukraini-v-tri-razi-zbilsilasa-kilkist-vikonanih-sudovih-risen-u-civilnih-ta-gospodarskih-spravah.

European Court of Human Rights. Ukraine (2020, January). Retrieved from https://www.echr.coe.int/Documents/CP_Ukraine_ENG.pdf.

Interfax Ukraine (2017, December 06). The level of execution of court decisions in Ukraine has tripled in a year - the Minister of Justice (in Ukrainian). Retrieved from https://ua.interfax.com.ua/news/general/46764o.html.

Izarova, I. (2011). Principle of openness in civil procedure and its content. Bulletin of the Taras Shevchenko National University of Kyiv. Legal Studies, 89, 66-69. (In Ukrainian).

Kroitor, V. (2004). Principle of openness content in civil procedure. Herald of the National university of internal affairs, 25, 354-360. (In Ukrainian).

Law of Ukraine "On Enforcement Proceedings", No. 1404-VIII (2016). Retrieved from http://zakono.rada.gov.ua/laws/show/1404-19/print.

Law of Ukraine "On the Bodies and Persons Who Execute the Enforcement of Court Decisions and Decisions of Other Bodies", No. 1403-VIII (2016). Retrieved from http://zakono.rada.gov.ua/laws/show/1403-19/print.

Law of Ukraine "On the access to the judicial decisions", No. 3262-IV (2005) Retrieved from https://zakon.rada.gov.ua/go/3262-15.

Lesiuk, T. (2005). Activities of the judiciary become more transparent. Legal review, No. 1(61), 5-17. (In Ukrainian).

Ministry of Justice of Ukraine (2019, August 13). State execution office presented the results of their work in the first part of 2019 year (in Ukrainian). Retrieved from https://minjust.gov.ua/news/ministry/derjavna-vikonavchaslujba-prezentuvala-rezultati-roboti-u-pershomu-pivrichchi-2019-roku?fbclid=IwARımPy64AvNHQZoLb9 _RGokm4EMrdbKvGL744wGG6jCRKvwsJYweKjJF9fY.

Ministry of Justice of Ukraine. Automated system of enforcement proceedings (2020). https://asvpweb.minjust.gov.ua/\#/search-debtors .

Recommendation Rec (2003)17 of the Committee of Ministers to member states on enforcement (2003, September 9). Retrieved from https://search.coe.int/cm/Pages/result_details.aspx?ObjectId=09000016805dfi35

Single State Web-Portal of Open Data. (2019, August 8). Evaluation of the work of state executive service bodies of the Main Territorial Administration of Justice in Kherson region. Enforcement on executive documents for collection of periodic payments in the first half of 2019. (in Ukrainian). Retrieved from https://data.gov.ua/dataset/fe8fbdd3-f2eo-4bb5-8f2c-6fd7dfi7bec8.

Snidevych, S.O. (2019). Publicity as a principle of the enforcement. Current problems of the national law, special issue, 72-75. (In Ukrainian). Retrieved from http://apnl.dnu.in.ua/2019/21.pdf.

The 2019 EU Justice Scoreboard (2019). Retrieved from https://ec.europa.eu/info/sites/info/files /justice_scoreboard_2019_en.pdf.

The Decree of the Cabinet of Ministers of Ukraine "On Approval of the Provision on Datasets to be Disclosed in the Form of Open Data" No. 835 (2015). Retrieved from https://zakon.rada.gov.ua/laws/show/835-2015-ח

The Global Goals For Sustainable Development, Goal 16 (2015). Retrieved from https://www.globalgoals.org/16peace-justice-and-strong-institutions .

Turkanova, V. (2020). Open Enforcement: New Approach of Ukraine in Access to Justice. Access to Justice in Eastern Europe, 1 (6), 58-68. DOI 10.33327/AJEE-18-3.1-poooo26.

United Nations (1948). Universal Declaration of Human Rights. Retrieved from https://www.un.org/en/universaldeclaration-human-rights/.

Uzelac, A. (2014). Goals of Civil Justice and Civil Procedure in the Contemporary World. In A. Uzelac (Ed.) Goals of Civil Justice and Civil Procedure in the Contemporary World. (Ius Gentium: Comparative Perspectives on Law and Justice 34, Pp. 3-31. Switzerland: Springer International Publishing.

Verkhovna Rada Ukrainy. Civil Procedure Code of Ukraine, No 1618-IV (2004). Retrieved from http://zakon2.rada.gov.ua/laws/show/1618-15/ed20040318/print.

Verkhovna Rada Ukrainy. Civil Procedure Code of Ukraine, No 2147-VIII (2017). Retrieved from http://zakon3.rada.gov.ua/laws/show/1618-15/print 
Verkhovna Rada Ukrainy. Civil Procedure Code, No 30 (1963). Retrieved from https://zakon.rada.gov.ua/laws/show/1501-o6.

Verkhovna Rada Ukrainy. Explanatory Statement for the Draft of Civil Procedure Code of Ukraine (2004). Retrieved from http://wi.c1.rada.gov.ua/pls/zweb2/webproc4_1?pf3511=1490o.

Verkhovna Rada Ukrainy. The bill on amendments to the Commercial Code of Ukraine, Civil Procedural Code of Ukraine, the Code of Administrative Procedure of Ukraine and other legislative acts No 6232 (2017). Retrieved from http://w1.c1.rada.gov.ua/pls/zweb2/webproc4_1?pf3511=61415. 